\title{
Modulation of Visceral Pain by Stress: Implications in Irritable Bowel Syndrome
}

\author{
Agata Mulak, Muriel Larauche and Yvette Taché \\ University of California Los Angeles \\ USA
}

\section{Introduction}

Stress-related changes in visceral perception resulting in enhanced sensitivity to physiological and/or experimental visceral stimuli along with hypervigilance are considered to play a critical role in the pathophysiology of irritable bowel syndrome (IBS) (Elsenbruch et al., 2010; Mayer et al., 2008; Mulak \& Bonaz, 2004; Posserud et al., 2004). Visceral hypersensitivity present in about two-thirds of IBS patients has been considered a biological marker in IBS (Bouin et al., 2002; Mertz et al., 1995). Numerous studies have also reported coexisting somatic hypersensitivity in IBS, although results are not unanimous (Chang et al., 2000; Iovino et al., 2006), most likely due to methodological issues, heterogeneity of IBS patient subgroups, or concomitant disorders (e.g., fibromyalgia) (Moshiree et al., 2007; Verne et al., 2001). The widespread character of hypersensitivity has been related to both peripheral and central mechanisms (Azpiroz et al., 2007; Piché et al., 2010). Alterations in the central nervous system (CNS) circuitries responsive to visceral input have been recently delineated in IBS patients compared with healthy subjects using functional brain imaging techniques (Song et al., 2006; Wilder-Smith et al., 2004). Evidence of spinal nociceptive facilitation in IBS has been also provided (Coffin et al., 2004).

Over the past 15 years, various animal models have been developed to gain a deeper insight into the central and peripheral mechanisms of visceral hypersensitivity (Holschneider et al., 2011; Mayer et al., 2008). However, only recently has the role of alterations in descending pain modulatory pathways in the pathophysiology of IBS and experimental models of IBS been recognized (Berman et al., 2008; Larauche et al., 2011a; Larauche et al., 2011b; WilderSmith et al., 2004). In this chapter, we will review the recent developments on stress-related modulation of visceral sensitivity to colorectal distension (CRD), with a special focus on alterations in stress-induced visceral analgesia and pain inhibitory mechanisms.

\section{Mechanisms of widespread hypersensitivity in IBS}

Several underlying mechanisms have been implicated independently or synergistically to account for the widespread hypersensitivity in IBS. Changes in excitability of central neurons and processes called 'central sensitization' contribute to the maintenance of secondary hyperalgesia (i.e. increased sensitivity to stimuli from uninjured tissues adjacent to or at some distance from the site of injury). Spinal sensitization could explain both visceral hypersensitivity and secondary hyperalgesia found in lumbosacral dermatomes, 
consistent with the viscerosomatic convergence on spinal neurons (Verne et al., 2001). In support of this contention, the local rectal application of lidocaine reversed visceral and cutaneous hyperalgesia in the lower limbs of IBS patients (Verne et al., 2003). Likewise, in animal models, $25 \%$ of rats receiving intracolonic administration of trinitrobenzene sulfonic acid to induce colitis displayed long-lasting hypersensitivity to both rectal distension and somatic stimuli such as heat stimulus applied to the foot or tail (Zhou et al., 2008). The hypersensitivity was the most pronounced in lumbosacral dermatomes, and intracolonic lidocaine administration normalized both rectal and somatic hypersensitivity (Zhou et al., 2008). In addition, an altered descending modulation (discussed in the next paragraph) may also play an important role. Pain facilitation processes associated with psychological factors are important components contributing to the hypersensitivity as well, along with pain inhibition deficits observed in IBS. In fact, heightened levels of anxiety and depression in IBS patients correlate with lower sensory thresholds to gut distension (Bouin et al., 2002; Posserud et al., 2004).

\section{Descending pain modulatory system}

The periaqueductal gray matter (PAG) and the nucleus raphe magnus, as well as nearby structures of the rostral ventromedial medulla (RVM) with their projections to the spinal dorsal horn, constitute a pain-control system that 'descends' from the brain onto the spinal cord (Vanegas \& Schaible, 2004). Importantly, this endogenous descending pain modulatory system consists not only of inhibitory, but also facilitatory pathways. Persistent nociception simultaneously triggers descending facilitation and inhibition. For instance, in models of inflammation following the subcutaneous injection of irritants, descending pain inhibition predominates over facilitation in response to input from the inflamed tissue, therefore attenuating primary hyperalgesia. In the case of secondary hyperalgesia, descending facilitation predominates over inhibition in pain circuits with input from adjacent tissues (Vanegas \& Schaible, 2004). The importance of facilitation of the spinal nociceptive processing has been recently recognized as a potential mechanism contributing to the pathophysiology of chronic pain conditions, including numerous functional disorders, such as IBS (Coffin et al., 2004). In these disorders characterized by persistent pain or discomfort without clearly defined tissue pathology, normally innocuous stimulation is incorrectly interpreted as noxious, which may originate from input to the RVM from sites rostral in the brain (e.g., via cortical, amygdalar or hypothalamic efferents), and be affected by a state of attention, anxiety, or cognitive perception (Urban \& Gebhart, 1999).

Numerous studies using inflammatory, neurogenic, or neuropathic models of hyperalgesia have shown that the RVM plays a key role in central sensitization which underlies the pathogenesis of chronic pain disorders. For example, visceral hyperalgesia associated with colonic inflammation could be reversed by the intra-RVM administration of an N-methyl-Daspartic acid receptor antagonist, suggesting tonic activity at glutamatergic synapses in the RVM (Coutinho et al., 1998). Other neuropeptide modulators present in the rodent RVM such as neurotensin or cholecystokinin have also been identified to be tonically active following peripheral tissue insult or inflammation (Friedrich \& Gebhart, 2003; Gui et al., 2004; Gebhart, 2004). A noteworthy aspect - in the RVM there are different electrophysiologically defined cells, termed $\mathrm{ON}$ cells, which are thought to facilitate nociception, and OFF cells that inhibit nociception processing (Mason, 2005). Descending inhibitory influences from the RVM are confined to the dorsolateral funiculi whereas 
facilitatory influences descend the spinal cord in the ventral/ventrolateral cord (Gebhart, 2004).

\section{Monitoring of visceral pain in rodents}

The assessment of pseudoaffective reflex responses (and to a lesser degree, behavioral responses) to controlled isobaric distensions of the distal colon has become the primary readout and the standard assay for the measurement of visceral pain in rodents since its development in 1988 by Ness and Gebhart (Ness \& Gebhart, 1988). When applied to rats, CRD produces a range of autonomic and behavioral pseudoaffective reflexes (changes in arterial pressure and heart rate, passive avoidance behaviors, and contraction of abdominal musculature). Monitoring the contraction of abdominal muscles or visceromotor response (VMR) is the most commonly used index of visceral pain response in rats and mice. In conscious animals, it can be directly assessed by electromyographic (EMG) signals monitored via surgically-implanted recording electrodes into the external or internal abdominal muscle, where the electrode device is either externalized through the skin (abdomen, neck) (Bradesi et al., 2005; Christianson \& Gebhart, 2007; Larsson et al., 2003) or connected to radiotelemetric implants into the abdominal cavity (Welting et al., 2005). Although the method is of significant value in the field of visceral pain, it has experimental shortfalls such as damage to EMG electrodes, loss of signal, and electrical interferences, which is of particular concern in chronic experimental settings. Additionally, EMG implantation requires surgery that encompasses skin and/or muscle incision depending on the technique used (subcutaneous abdominal electrodes or intraperitoneal cannula) and chronic implantation of a foreign body. Even though no data are available in the literature in relation to the immune impact of chronic EMG electrodes placed into the abdominal wall, such intervention could induce a host-tissue response with local micro-inflammation (neutrophils, lymphocytes and macrophages) as it has been shown for other types of implants in the skin and peritoneum (Klueh \& Kreutzer, 2005). A recent report suggests that the preconditions of animals (EMG surgery, post-surgical delivery of antibiotic and single housing) have a considerable impact on the visceral pain responses to CRD, particularly in the context of stress studies (Larauche et al., 2010). Other approaches consist of recording manometric changes in the pressure of the balloon inserted into the distal colon (Arvidsson et al., 2006) or changes in pressure inside the colonic lumen (Larauche et al., 2009; Larauche et al., 2010). These two techniques present the advantage of being minimally invasive as they do not require surgery and post-surgical treatments such as antibiotics or analgesics which can affect the visceral pain responses and still remain an objective and sensitive measure of abdominal contractions. However, they entail the partial restraint of animals in Bollman cages, a context to which they need to be habituated and which by itself may bring a component of stress. Behavioral approaches such as operant behavioral assays (Ness \& Gebhart, 1988) have also been used in early studies and capitalized on the learning and fear behaviors of animals in response to painful CRD. Furthermore, visual monitoring of the abdominal withdrawal reflex (Al-Chaer et al., 2000) has been applied in a few studies, and while having the great advantage of being one of the less invasive techniques employed to date, it is a very subjective method. Indirect endpoints, such as the marker of neuronal activation, Fos protein or extracellular signal-regulated protein kinase expression induced in neurons at specific sites in the CNS (Million et al., 2006; Wu et al., 2010), as well as functional brain imaging of integrated brain responses to nociceptive stimuli (Wang et al., 
2008), have also been utilized in some animal studies. These approaches allow for direct assessment of neuronal circuitries activated by the visceral pain stimulus and, in the case of functional brain imaging, are very similar to the monitoring of CRD responses in IBS patients and healthy subjects. Unfortunately, in animals these brain mapping techniques require euthanasia and limit the assessment to specific time points. However, as more stringent brain imaging approaches are developed in rodents, they will open new venues to parallel human studies (Coello et al., 2011; Lee et al., 2010).

We recently developed an alternative non-invasive method to study visceral sensitivity to CRD in conscious mice, using a commercially-available miniaturized pressure catheter to record intraluminal colonic pressure (ICP) (Larauche et al., 2010). Briefly, a PE50 catheter was taped $2 \mathrm{~cm}$ below the pressure sensor of a miniaturized pressure transducer catheter (SPR-524 Mikro-Tip catheter; Millar Instruments, Houston, TX). A custom-made balloon (1cm width x 2-cm length) (Arvidsson et al., 2006; Christianson \& Gebhart, 2007; Kamp et al., 2003) prepared from a polyethylene plastic bag was tied over the catheter at $1 \mathrm{~cm}$ below the pressure sensor with silk 4.0. Ligature points were covered with parafilm to prevent any air from leaking. To validate the technique, we monitored the VMR to graded phasic CRD by simultaneously recording ICP and EMG signals in mice chronically implanted with electrodes. We found an excellent correlation between signals from ICP and EMG during consecutive ascending phasic distensions between 15 to $60 \mathrm{mmHg}$ when recorded simultaneously in the same mice. We also showed that the colonic pain pressure threshold to CRD detected by both methods were similar (about $32 \mathrm{mmHg}$ ), and consistent with values previously reported using EMG and manometry (Arvidsson et al., 2006; Kamp et al., 2003). As colonic pressure could be altered following abdominal contractions and/or contractions of the colonic wall, we assessed the effects of atropine, a muscarinic blocker known to inhibit colonic motility (Gourcerol et al., 2009), on the VMR to CRD monitored by ICP in naïve mice (Larauche et al., 2010). We found that atropine did not significantly modify the phasic CRD-associated ICP changes (Larauche et al., 2010), while inhibiting distal colonic motility measured by ICP changes in conscious mice maintained under similar recording conditions (Gourcerol et al., 2009). In addition, with the use of the non-invasive method, it has been confirmed that buprenorphine, a partial agonist for mu-opioid receptors, inhibited visceral sensitivity to graded phasic ascending CRD which is consistent with opioid-induced reduction of basal visceral response to CRD in both rats and mice (Danzebrink et al., 1995; Larsson et al., 2003). Conversely, an hyperalgesic response to CRD can be induced after the intraperitoneal injection of cortagine, a selective corticotropin releasing factor receptor subtype $1\left(\mathrm{CRF}_{1}\right)$ agonist, known to act directly on the $\mathrm{CRF}_{1}$ receptor expressed in the colon (Larauche et al., 2009). A similar, non-invasive method to monitor VMR has also been validated in rats (Larauche et al., 2009). Taken together, these data have established the reliability of ICP method to assess the modulation of visceral sensitivity in conscious rodents (Larauche et al., 2010).

\section{Stress-induced modulation of visceral pain}

By convention, stressors are categorized as exteroceptive (psychological or neurogenic) and interoceptive (physical, systemic, visceral or immune) (Herman \& Cullinan, 1997; Sawchenko et al., 2000). Both have been applied to rodents to investigate the relationship between stress and visceral pain modulation (Mayer \& Collins, 2002). Dual visceral pain responses - hyperalgesia and analgesia have been described in rodents. Stress-induced 
hyperalgesia has been examined in detail in several recent reviews (Larauche et al., 2011a; Larauche et al., 2011b; Mayer, 2008) to which the reader is referred to. By contrast, while extensively described in the somatic pain field (Butler \& Finn, 2009), to date stress-related activation of descending inhibitory pathways under conditions of visceral pain has received less attention. Opioids have been implicated in descending inhibition of visceral sensitivity to CRD following an acute stress. This is evidenced by the fact that naloxone unmasked water avoidance stress (WAS)-induced hyperalgesia to CRD in normal Long-Evans rats and exacerbated the pain response to CRD in maternally-separated rats (Coutinho et al., 2002). In another study, a non-opioid, neurotensin-dependent visceral analgesic response was induced in wild-type mice $6 \mathrm{~h}$ after exposure to an acute session of WAS, while neurotensin knock-out mice under the same conditions had no analgesia (Gui et al., 2004). In addition, male Sprague-Dawley rats exhibited stronger analgesia to WAS than females (Gui et al., 2004). In another experimental model, a daily short period (15 min) pup separation from the mother, occurring from postnatal days 2 to 14, decreased VMR to CRD performed immediately after WAS and prevented the development of hyperalgesia $24 \mathrm{~h}$ after WAS in adult male Long-Evans rats (Schwetz et al., 2005). These data suggest a potential upregulation of endogenous pain-modulatory systems by this short maternal separation stress (Schwetz et al., 2005). Similar findings have been recently reported in adult Wistar rats handled daily for 9 days which develop visceral hypoalgesia in response to CRD that becomes significant 7 days after the last handling (Winston et al., 2010). These studies point to different types of mild psychological or environmental stressors-induced naloxone dependent or independent visceral analgesia as reported for somatic pain (Butler \& Finn, 2009) and indicate a potential sex difference in such a stress-related analgesic response.

However, importantly, we recently demonstrated that mice that had undergone surgery for the placement of EMG electrodes on the abdominal wall and were subsequently singly housed to avoid deterioration of the implanted electrodes by cage-mates, developed visceral hyperalgesia in response to repeated WAS (1h/day for 10 consecutive days), while mice tested for visceral pain using the non-invasive solid-state intraluminal pressure recording and kept group housed, developed a strong visceral analgesia under otherwise similar conditions of repeated intermittent WAS (Larauche et al., 2010). Collectively, these data demonstrate that the state of the tested animal (naïve vs exposed to surgery), its social environment (group housing vs single housing, cage enrichment or not), the handling performed by the investigator, the methods used to record visceromotor responses (EMG requiring surgery and antibiotic post surgery vs manometry not requiring surgery/antibiotic), as well as the animal sex can significantly affect the analgesic response to exteroceptive stressors. Therefore these preconditions should be carefully detailed in describing the experimental setting and taken into consideration in the study design and interpretations of the data when investigating the influence of stress on visceral sensitivity in experimental animals.

\section{Deficit in pain inhibition in IBS}

The stress-related analgesic response bears very relevant implications to the understanding of analgesic mechanisms that can be impaired in visceral pain-associated pathologies such as IBS. Deficits in stress-related descending pain inhibition may lay at the origin of both somatic and visceral hypersensitivity. Alteration in pain inhibitory modulation was observed in IBS patients under conditions of counter-irritation, a clinically well-recognized 
phenomenon frequently described as "pain inhibits pain" (Le Bars et al., 1979; Wilder-Smith et al., 2004). It occurs when response from a painful stimulus is inhibited by another, often spatially distant and noxious and relates to mechanisms named diffuse noxious inhibitory controls (DNICs) (Le Bars et al., 1979). Counter-irritation modulated via CNS mechanisms usually produces robust pain inhibition with residual analgesia persisting during the recovery period. Studies using the DNIC model to quantify the central pain sensitization in patients with chronic pain syndrome showed that defective DNIC is a risk factor for developing these disorders (Edwards et al., 2003; Lautenbacher \& Rollman, 1997). Interestingly, many IBS patients display a reduced inhibition of evoked somatic or rectal pain that normally occur when a noxious stimulus is simultaneously applied to another body area, e.g. hot or cold water immersion tests (King et al., 2009; Wilder-Smith et al., 2004). Recent studies assessing the correlation between visceral and somatic hypersensitivity in diarrheapredominant IBS patients have shown that patients with rectal hypersensitivity display a clear concomitant deficit in somatic pain inhibition (Piché et al., 2010). The observed somatic hypersensitivity to cutaneous heat stimulation involved different regions of the body but was more pronounced in dermatomes in which afferents converge on spinal neurons receiving bowel afferents. These data suggest that the coexisting visceral and somatic hypersensitivity may depend on both viscerosomatic convergence and generalized spinal hyperexcitability (Piché et al., 2010). A deficit in endogenous pain modulation and somatic hypersensitivity have also been demonstrated in other recent studies in IBS patients (Heymen et al., 2010; Wilder-Smith et al. 2004). Moreover, the spinal transmission of nociceptive signals in IBS patients was investigated by analyzing the effects of rectal distensions on EMG recordings of the somatic nociceptive flexion (RIII) reflex, an objective index of spinal somatic nociceptive processes (Coffin et al., 2004). The results indicated that the RIII reflex was significantly facilitated during slow ramp distension, whereas inhibitions induced by rapid distensions were significantly reduced in IBS patients compared to healthy controls (Coffin et al., 2004). Therefore both reduction in inhibition and active facilitation could contribute to central sensitization and secondary hyperalgesia in IBS (Price et al., 2009).

\section{Conclusions}

Based on recent clinical findings demonstrating that IBS patients have a compromised engagement of the inhibitory descending pain modulation systems (Berman et al., 2008; Coffin et al., 2004; Piché et al., 2010; Song et al., 2006; Wilder-Smith et al., 2004), gaining a deeper understanding of mechanisms involved in the expression of stress-induced visceral analgesia, or lack thereof, are promising avenues to be explored and may lead to new therapeutic targets for IBS. Therefore the use of non-invasive methods of monitoring VMR that allows the unraveling of the analgesic influence of stress on visceral pain represents a step forward to gain insight into the underlying mechanisms, in particular the neural substrates and neurochemistry of stress-related analgesia as established in the somatic pain field (Butler \& Finn, 2009).

\section{Acknowledgements}

This review is supported by the VA Research Career Scientist Award, NIH grants R01 DK57238 and DK 33061 and P50 DK-64539 (YT) and K01 DK088937 (ML). The authors thank Ms. Eugenia Hu for reviewing the manuscript. 


\section{References}

Al-Chaer, E.D.; Kawasaki, M. \& Pasricha, P.J. (2000). A new model of chronic visceral hypersensitivity in adult rats induced by colon irritation during postnatal development. Gastroenterology, 119, 5, pp. 1276-1285, ISSN 0016-5085

Arvidsson, S.; Larsson, M.; Larsson, H.; Lindström, E. \& Martinez, V. (2006). Assessment of visceral pain-related pseudo-affective responses to colorectal distension in mice by intracolonic manometric recordings. J. Pain, 7, 2, pp. 108-118, ISSN 1526-5900

Azpiroz, F.; Bouin, M.; Camilleri, M.; Mayer, E.A.; Poitras, P.; Serra, J. \& Spiller, R.C. (2007). Mechanisms of hypersensitivity in IBS and functional disorders. Neurogastroenterol. Motil., 19, 1 Suppl, pp. 62-88, ISSN 1350-1925

Berman, S.M.; Naliboff, B.D.; Suyenobu, B.; Labus, J.S.; Stains, J.; Ohning, G.; Kilpatrick, L.; Bueller, J.A.; Ruby, K.; Jarcho, J. \& Mayer, E.A. (2008). Reduced brainstem inhibition during anticipated pelvic visceral pain correlates with enhanced brain response to the visceral stimulus in women with irritable bowel syndrome. $J$. Neurosci., 28, 2, pp. 349-359, ISSN 0270-6474

Bouin, M.; Plourde, V.; Boivin, M.; Riberdy, M.; Lupien, F.; Laganière, M.; Verrier, P. \& Poitras, P. (2002). Rectal distention testing in patients with irritable bowel syndrome: sensitivity, specificity, and predictive values of pain sensory thresholds. Gastroenterology, 122, 7, pp. 1771-1777, ISSN 0016-5085

Bradesi, S.; Schwetz, I.; Ennes, H.S.; Lamy, C.M.; Ohning, G.; Fanselow, M.; Pothoulakis, C.; McRoberts, J.A. \& Mayer, E.A. (2005). Repeated exposure to water avoidance stress in rats: a new model for sustained visceral hyperalgesia. Am. J. Physiol. Gastrointest. Liver Physiol., 289, 1, pp. G42-G53, ISSN 0193-1857

Butler, R.K. \& Finn, D.P. (2009). Stress-induced analgesia. Prog. Neurobiol., 88, 3, pp. 184-202, ISSN 0301-0082

Chang, L.; Mayer, E.A.; Johnson, T.; FitzGerald, L.Z. \& Naliboff, B. (2000). Differences in somatic perception in female patients with irritable bowel syndrome with and without fibromyalgia. Pain, 84, 2-3, pp. 297-307, ISSN 0304-3959

Christianson, J.A. \& Gebhart, G.F. (2007). Assessment of colon sensitivity by luminal distension in mice. Nat. Protoc., 2, 10, pp. 2624-2631, ISSN 1754-2189

Coello, C.; Hjornevik, T.; Courivaud, F. \& Willoch, F. (2011). Anatomical standardization of small animal brain FDG-PET images using synthetic functional template: Experimental comparison with anatomical template. J. Neurosci. Methods, 199, 1, pp. 166-172, ISSN 0165-0270

Coffin, B.; Bouhassira, D.; Sabate, J.M.; Barbe, L. \& Jian, R. (2004). Alteration of the spinal modulation of nociceptive processing in patients with irritable bowel syndrome. Gut, 53, 10, pp. 1465-1470, ISSN 0017-5749

Coutinho, S.V.; Plotsky, P.M.; Sablad, M.; Miller, J.C.; Zhou, H.; Bayati, A.I.; McRoberts, J.A. \& Mayer, E.A. (2002). Neonatal maternal separation alters stress-induced responses to viscerosomatic nociceptive stimuli in rat. Am. J. Physiol. Gastrointest. Liver Physiol., 282, 2, pp. G307-G316, ISSN 0193-1857

Coutinho, S.V.; Urban, M.O. \& Gebhart, G.F. (1998). Role of glutamate receptors and nitric oxide in the rostral ventromedial medulla in visceral hyperalgesia. Pain, 78, 1, pp. 59-69, ISSN 0304-3959

Danzebrink, R.M.; Green, S.A. \& Gebhart, G.F. (1995). Spinal mu and delta, but not kappa, opioid-receptor agonists attenuate responses to noxious colorectal distension in the rat. Pain, 63, 1, pp. 39-47, ISSN 0304-3959 
Edwards, R.R.; Ness, T.J.; Weigent, D.A. \& Fillingim, R.B. (2003). Individual differences in diffuse noxious inhibitory controls (DNIC): association with clinical variables. Pain, 106, 3, pp. 427-437, ISSN 0304-3959

Elsenbruch, S.; Rosenberger, C.; Bingel, U.; Forsting, M.; Schedlowski, M. \& Gizewski, E.R. (2010). Patients with irritable bowel syndrome have altered emotional modulation of neural responses to visceral stimuli. Gastroenterology, 139, 4, pp. 1310-1319, ISSN 0016-5085

Friedrich, A.E. \& Gebhart, G.F. (2003). Modulation of visceral hyperalgesia by morphine and cholecystokinin from the rat rostroventral medial medulla. Pain, 104, 1-2, pp. 93101, ISSN 0304-3959

Gebhart, G.F. (2004). Descending modulation of pain. Neurosci. Biobehav. Rev., 27, 8, pp. 729737, ISSN 0149-7634

Gourcerol, G.; Wang, L.; Adelson, D.W.; Larauche, M.; Taché, Y. \& Million, M. (2009). Cholinergic giant migrating contractions in conscious mice colon assessed by using a novel non-invasive solid-state manometry method: modulation by stressors. Am. J. Physiol. Gastrointest. Liver Physiol., 296, 5, pp. G992-G1002, ISSN 0193-1857

Gui, X.; Carraway, R.E. \& Dobner, P.R. (2004). Endogenous neurotensin facilitates visceral nociception and is required for stress-induced antinociception in mice and rats. Neuroscience, 126, 4, pp. 1023-1032, ISSN 0306-4522

Herman, J.P. \& Cullinan, W.E. (1997). Neurocircuitry of stress: central control of the hypothalamo-pituitary-adrenocortical axis. Trends Neurosci., 20, 2, pp. 78-84, ISSN 0166-2236

Heymen, S.; Maixner, W.; Whitehead, W.E.; Klatzkin, R.R.; Mechlin, B. \& Light, K.C. (2010). Central processing of noxious somatic stimuli in patients with irritable bowel syndrome compared with healthy controls. Clin. J. Pain, 26, 2, pp. 104-109, ISSN 1536-5409

Holschneider, D.P.; Bradesi, S. \& Mayer, E.A. (2011). The role of experimental models in developing new treatments for irritable bowel syndrome. Expert. Rev. Gastroenterol. Hepatol., 5, 1, pp. 43-57, ISSN 1747-4124

Iovino, P.; Tremolaterra, F.; Consalvo, D.; Sabbatini, F.; Mazzacca, G. \& Ciacci, C. (2006). Perception of electrocutaneous stimuli in irritable bowel syndrome. Am. J. Gastroenterol., 101, 3, pp. 596-603, ISSN 0002-9270

Kamp, E.H.; Jones, R.C., III; Tillman, S.R. \& Gebhart, G.F. (2003). Quantitative assessment and characterization of visceral nociception and hyperalgesia in mice. Am. J. Physiol. Gastrointest. Liver Physiol., 284, 3, pp. G434-G444, ISSN 0193-1857

King, C.D.; Wong, F.; Currie, T.; Mauderli, A.P.; Fillingim, R.B. \& Riley, J.L., 3rd (2009). Deficiency in endogenous modulation of prolonged heat pain in patients with Irritable Bowel Syndrome and Temporomandibular Disorder. Pain, 143, 3, pp. 172178, ISSN 0304-3959

Klueh, U. \& Kreutzer, D.L. (2005). Murine model of implantable glucose sensors: a novel model for glucose sensor development. Diabetes Technol. Ther., 7, 5, pp. 727-737, ISSN 1520-9156

Larauche, M.; Gourcerol, G.; Million, M.; Adelson, D.W. \& Taché, Y. (2010). Repeated psychological stress-induced alterations of visceral sensitivity and colonic motor functions in mice: Influence of surgery and postoperative single housing on visceromotor responses. Stress, 13, 4, pp. 343-354, ISSN 1025-3890

Larauche, M.; Gourcerol, G.; Wang, L.; Pambukchian, K.; Brunnhuber, S.; Adelson, D.W.; Rivier, J.; Million, M. \& Taché, Y. (2009). Cortagine, a CRF1 agonist, induces stresslike alterations of colonic function and visceral hypersensitivity in rodents 
primarily through peripheral pathways. Am. J. Physiol. Gastrointest. Liver Physiol., 297, 1, pp. G215-G227, ISSN 0193-1857

Larauche, M.; Mulak, A. \& Taché, Y. (2011a). Stress and visceral pain: From animal models to clinical therapies. Exp. Neurol., Published Online First doi:10.1016/j.expneurol.2011.04.020, ISSN 0014-4886

Larauche, M.; Mulak, A. \& Taché, Y. (2011b). Stress-related alterations of visceral sensation: animal models for IBS study. J. Neurogastroenterol. Motil., Published Online First doi:10.5056/jnm.2011.17.3.212., ISSN 2093-0879

Larsson, M.; Arvidsson, S.; Ekman, C. \& Bayati, A. (2003). A model for chronic quantitative studies of colorectal sensitivity using balloon distension in conscious mice - effects of opioid receptor agonists. Neurogastroenterol. Motil., 15, 4, pp. 371-381, ISSN 1350-1925

Lautenbacher, S. \& Rollman, G.B. (1997). Possible deficiencies of pain modulation in fibromyalgia. Clin. J. Pain, 13, 3, pp. 189-196, ISSN 1536-5409

Le Bars, B.D.; Dickenson, A.H. \& Besson, J.M. (1979). Diffuse noxious inhibitory controls (DNIC). I. Effects on dorsal horn convergent neurones in the rat. Pain, 6, 3, pp. 283304, ISSN 0304-3959

Lee, J.H.; Durand, R.; Gradinaru, V.; Zhang, F.; Goshen, I.; Kim, D.S.; Fenno, L.E.; Ramakrishnan, C. \& Deisseroth, K. (2010). Global and local fMRI signals driven by neurons defined optogenetically by type and wiring. Nature, 465, 7299, pp. 788-792, ISSN 0028-0836

Mason, P. (2005). Ventromedial medulla: pain modulation and beyond. J. Comp. Neurol., 493, 1, pp. 2-8, ISSN 0021-9967

Martinez, V.; Thakur, S.; Mogil, J.S.; Taché, Y. \& Mayer, E.A. (1999). Differential effects of chemical and mechanical colonic irritation on behavioral pain response to intraperitoneal acetic acid in mice. Pain, 81, 1-2, pp. 179-186, ISSN 0304-3959

Mayer, E.A.; Bradesi, S.; Chang, L.; Spiegel, B.M.; Bueller, J.A. \& Naliboff, B.D. (2008). Functional GI disorders: from animal models to drug development. Gut, 57, 3, pp. 384-404, ISSN 0017-5749

Mayer, E.A. \& Collins, S.M. (2002). Evolving pathophysiologic models of functional gastrointestinal disorders. Gastroenterology, 122, 7, pp. 2032-2048, ISSN 0016-5085

Mertz, H.; Naliboff, B.; Munakata, J.; Niazi, N. \& Mayer, E.A. (1995). Altered rectal perception is a biological marker of patients with irritable bowel syndrome. Gastroenterology, 109, 1, pp. 40-52, ISSN 0016-5085

Million, M.; Wang, L.; Wang, Y.; Adelson, D.W.; Yuan, P.Q.; Maillot, C.; Coutinho, S.V.; McRoberts, J.A.; Bayati, A.; Mattsson, H.; Wu, V.; Wei, J.Y.; Rivier, J.; Vale, W.; Mayer, E.A. \& Taché, Y. (2006). CRF2 receptor activation prevents colorectal distension induced visceral pain and spinal ERK1/2 phosphorylation in rats. Gut, 55, 2, pp. 172-181, ISSN 0017-5749

Moshiree, B.; Price, D.D.; Robinson, M.E.; Gaible, R. \& Verne, G.N. (2007). Thermal and visceral hypersensitivity in irritable bowel syndrome patients with and without fibromyalgia. Clin. J. Pain, 23, 4, pp. 323-330, ISSN 1536-5409

Mulak, A. \& Bonaz, B. (2004). Irritable bowel syndrome: a model of the brain-gut interactions. Med. Sci. Monit., 10, 4, pp. RA55-62, ISSN 1234-1010

Ness, T.J. \& Gebhart, G.F. (1988). Colorectal distension as a noxious visceral stimulus: physiologic and pharmacologic characterization of pseudaffective reflexes in the rat. Brain Res., 450, 1-2, pp. 153-169, ISSN 0006-8993

Piché, M.; Arsenault, M.; Poitras, P.; Rainville, P. \& Bouin, M. (2010). Widespread hypersensitivity is related to altered pain inhibition processes in irritable bowel syndrome. Pain, 148, 1, pp. 49-58, ISSN 0304-3959 
Posserud, I.; Agerforz, P.; Ekman, R.; Bjornsson, E.S.; Abrahamsson, H. \& Simren, M. (2004). Altered visceral perceptual and neuroendocrine response in patients with irritable bowel syndrome during mental stress. Gut, 53, 8, pp. 1102-1108, ISSN 0017-5749

Price, D.D.; Craggs, J.G.; Zhou, Q.; Verne, G.N.; Perlstein, W.M. \& Robinson, M.E. (2009). Widespread hyperalgesia in irritable bowel syndrome is dynamically maintained by tonic visceral impulse input and placebo/nocebo factors: evidence from human psychophysics, animal models, and neuroimaging. Neuroimage, 47, 3, pp. 995-1001, ISSN 1053-8119

Sawchenko, P.E.; Li, H.Y. \& Ericsson, A. (2000). Circuits and mechanisms governing hypothalamic responses to stress: a tale of two paradigms. Prog. Brain Res., 122, 6178, ISSN 0079-6123

Schwetz, I.; McRoberts, J.A.; Coutinho, S.V.; Bradesi, S.; Gale, G.; Fanselow, M.; Million, M.; Ohning, G.; Taché, Y.; Plotsky, P.M. \& Mayer, E.A. (2005). Corticotropin-releasing factor receptor 1 mediates acute and delayed stress-induced visceral hyperalgesia in maternally separated Long-Evans rats. Am. J. Physiol. Gastrointest. Liver Physiol., 289, 4, pp. G704-G712, ISSN 0193-1857

Song, G.H.; Venkatraman, V.; Ho, K.Y.; Chee, M.W.; Yeoh, K.G. \& Wilder-Smith, C.H. (2006). Cortical effects of anticipation and endogenous modulation of visceral pain assessed by functional brain MRI in irritable bowel syndrome patients and healthy controls. Pain, 126, 1-3, pp. 79-90, ISSN 0304-3959

Urban, M.O. \& Gebhart G.F. (1999). Central mechanisms in pain. Med. Clin. North Am., 83, 3, pp. 585-596, ISSN 0025-7125

Vanegas, H. \& Schaible, H.G. (2004). Descending control of persistent pain: inhibitory or facilitatory? Brain Res. Rev., 46, 3, pp. 295-309, ISSN 0165-0173

Verne, G.N.; Robinson, M.E. \& Price, D.D. (2001). Hypersensitivity to visceral and cutaneous pain in the irritable bowel syndrome. Pain, 93, 1, pp. 7-14, ISSN 0304-3959

Verne, G.N.; Robinson, M.E.; Vase, L. \& Price, D.D. (2003). Reversal of visceral and cutaneous hyperalgesia by local rectal anesthesia in irritable bowel syndrome (IBS) patients. Pain, 105, 1-2, pp. 223-230, ISSN 0304-3959

Wang, Z.; Bradesi, S.; Maarek, J.M.; Lee, K.; Winchester, W.J.; Mayer, E.A. \& Holschneider, D.P. (2008). Regional brain activation in conscious, nonrestrained rats in response to noxious visceral stimulation. Pain, 138, 1, pp. 233-243, ISSN 0304-3959

Welting, O.; van den Wijngaard, R.M.; de Jonge, W.J.; Holman, R. \& Boeckxstaens, G.E. (2005). Assessment of visceral sensitivity using radio telemetry in a rat model of maternal separation. Neurogastroenterol. Motil., 17, 6, pp. 838-845, ISSN 1350-1925

Wilder-Smith, C.H.; Schindler, D.; Lovblad, K.; Redmond, S.M. \& Nirkko, A. (2004). Brain functional magnetic resonance imaging of rectal pain and activation of endogenous inhibitory mechanisms in irritable bowel syndrome patient subgroups and healthy controls. Gut, 53, 11, pp. 1595-1601, ISSN 0017-5749

Winston, J.H.; Xu, G.Y. \& Sarna, S.K. (2010). Adrenergic stimulation mediates visceral hypersensitivity to colorectal distension following heterotypic chronic stress. Gastroenterology, 138, 1, pp. 294-304, ISSN 0016-5085

Wu, J.C.; Ziea, E.T.; Lao, L.; Lam, E.F.; Chan, C.S.; Liang, A.Y.; Chu, S.L.; Yew, D.T.; Berman, B.M. \& Sung, J.J. (2010). Effect of electroacupuncture on visceral hyperalgesia, serotonin and fos expression in an animal model of irritable bowel syndrome. $J$. Neurogastroenterol. Motil., 16, 3, pp. 306-314, ISSN 2093-0879

Zhou, Q.; Price, D.D. \& Verne, G.N. (2008). Reversal of visceral and somatic hypersensitivity in a subset of hypersensitive rats by intracolonic lidocaine. Pain, 139, 1, pp. 218-224, ISSN 0304-3959 


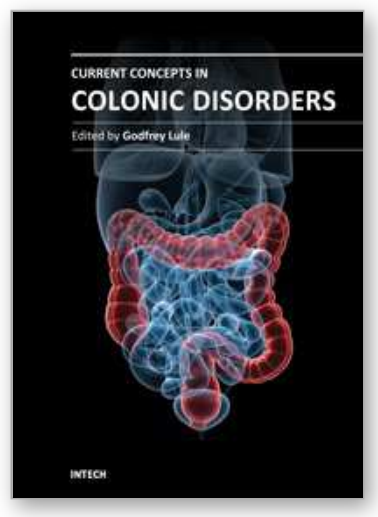

\author{
Current Concepts in Colonic Disorders \\ Edited by Dr. Godfrey Lule
}

ISBN 978-953-307-957-8

Hard cover, 276 pages

Publisher InTech

Published online 05, January, 2012

Published in print edition January, 2012

The 21 st Century has seen a resurgence of research of the gastrointestinal tract, especially since it was established that it plays a central role as an immune system organ and consequentially has a huge impact on causation, impact and transmission of most human ailments. New diseases such as the Acquired Immunodeficiency Syndrome, hepatitis and tumours of the gastrointestinal tract have emerged and they are currently subjects of intensive research and topics of scientific papers published worldwide. Old diseases like diarrhea have become extremely complex to diagnose with new and old pathogens, drugs, tumours and malabsorptive disorders accounting for the confusion. This book has set out algorithms on how to approach such conditions in a systematic way both to reach a diagnosis and to make patient management cheaper and more efficient. "Current Concepts in Colonic Disorders" attempts to put all the new information into proper perspective with emphasis on aetiopathogenesis and providing rational approach to management of various old and new diseases. As the book editor, I have found this first edition extremely interesting and easy to understand. Comments on how to improve the content and manner of presentation for future editions are extremely welcome.

\title{
How to reference
}

In order to correctly reference this scholarly work, feel free to copy and paste the following:

Agata Mulak, Muriel Larauche and Yvette Tache (2012). Modulation of Visceral Pain by Stress: Implications in Irritable Bowel Syndrome, Current Concepts in Colonic Disorders, Dr. Godfrey Lule (Ed.), ISBN: 978-953-307957-8, InTech, Available from: http://www.intechopen.com/books/current-concepts-in-colonicdisorders/modulation-of-visceral-pain-by-stress-implications-in-irritable-bowel-syndrome

\section{INTECH}

open science | open minds

\section{InTech Europe}

University Campus STeP Ri

Slavka Krautzeka 83/A

51000 Rijeka, Croatia

Phone: +385 (51) 770447

Fax: +385 (51) 686166

www.intechopen.com

\section{InTech China}

Unit 405, Office Block, Hotel Equatorial Shanghai

No.65, Yan An Road (West), Shanghai, 200040, China 中国上海市延安西路65号上海国际贵都大饭店办公楼 405 单元

Phone: +86-21-62489820

Fax: $+86-21-62489821$ 
(C) 2012 The Author(s). Licensee IntechOpen. This is an open access article distributed under the terms of the Creative Commons Attribution 3.0 License, which permits unrestricted use, distribution, and reproduction in any medium, provided the original work is properly cited. 